\title{
Energy Efficiency Promotion and Conservation Measures
}

\author{
Muhammad Shahzad Nazir* \\ Faculty of Automation, Huaiyin Institute of Technology, PR China \\ *Corresponding author: Muhammad Shahzad Nazir, Faculty of Automation, Huaiyin Institute of Technology, Huai'an 223003, Jiangsu, \\ PR China
}

\section{Introduction}

Pakistan's energy crisis has been brewing for last one decade, but it was deepened in 2016-17 with power shortage increased to 5000 MW. The installed electricity generation capacity of Pakistan is $23636 \mathrm{MW}$, which is not fully exploited as plants operate at less efficiency or remain shut down due to non-payment of circular debt. Energy shortfall resulted in introduction of load shedding program which cost about 8 billion US $\$$ to the economy every year. The situation has further compounded due to high transmission and distribution losses (20\%), theft of electricity, declining revenue collection and corruption, etc. Due to inadequate domestic oil reserves, Pakistan spends about US\$ 15.473 billion every year (2016) on the import of oil and petroleum products to meet her energy demand. Agriculture is an important sector of the economy of Pakistan, which contributes about $21 \%$ of Gross Domestic Product (GDP) and generates productive employment opportunities for $45 \%$ of the country's labor force. Besides meeting the food and fiber requirements of the local population, it also supports other sectors of economy such as manufacturing and services because of having robust horizontal and vertical linkages with them.

Due to its significant position in the economy, and efficient, productive, and profitable agriculture sector can play a vital role in ensuring food security, generating overall economic growth, reducing poverty, and the country's transformation towards industrialization. With less than $240 \mathrm{~mm}$ of rainfall annually, Pakistan is considered a high-water stress region. The country's agriculture and hence the economy is heavily dependent on availability of irrigation water, which is currently inadequate in terms of meeting the requirements. To benefit from agriculturedriven economic growth, investments in irrigation infrastructure are imperative. Diesel and electricity prices have decreased contribution by groundwater, which is the main reason for the low availability of water for irrigation.

\section{Energy Efficiency Issues}

The power losses in the distribution system of Pakistan are $20 \%-35 \%$ and can be minimized by using smart grids, quality electric equipment and monitoring of power. Pakistan can save 15 billion US\$ using energy efficiency techniques, equivalent to the cost of imported oil in a year. In Punjab province potential for saving energy losses at 27\% in domestic, 20\% (industry), 29\% (agriculture) and 40\% (streetlights) have been assessed by promoting energy efficiency measures (EECMs) and awareness amongst the end-users. The need for promoting EECMs shall be felt strongly in the future as Pakistan will require 50,000 MW of electricity in 2025. This will lead to more dependence on import of energy as well following two-prong strategy to bridge the gap between demand and supply. i.e. Increase the power supply through new capacity additions and improve sector performance, and b). Curb the desire through demand-side management (promote EECMs). The energy gap will, however, continue to exist until both measures are effectively implemented. Increasing the supply capacity takes long time and is expensive, while energy efficiency is the least-cost option. Both options may be applied at the same time.

The sectors requiring an immediate focus of energy efficiency measures include:

a. Domestic and commercial sectors include lighting, fans, air-conditioning, water pumping, cooking, space heating, water heating, and other appliances.

b. The industrial sector includes electricity, natural gas, oil, coal used in fertilizer, cement, sugar, pulp and paper, iron and steel, brick making, and other industries.

c. The transportation sector includes petroleum products, natural gas, and electricity use in vehicles, railways, and mass transit systems.

\section{Energy Efficiency of Agriculture Tube-wells}

There are more than one million agricultural tube-wells $(0.9$ million diesel \& 0.12 million electric), which are operated by farmers for irrigation of crops in the Punjab Province. The majority (85\%) of the tube-well have up to $20 \mathrm{HP}$ diesel engine or electric motor. The operational and maintenance costs of tube-well are high due 
to non-standardization and certification facilities, improper size of the engine, motor and pumping system, poor quality of materials used for manufacturing of tube well components, and non-qualified staff hired by manufacturers. The quality of locally manufactured pumps and other components is not as per international standards, and imported systems are costly and beyond the scope of an ordinary farmer. There is no government regulatory body that may check the quality of tube-well components manufactured locally and certify the equipment. The farmers also need technical guidance for selection of energy-efficient tube well components and its installation by qualified engineers. They also need training for efficient operation and maintenance of pumping systems and groundwater management. The operational cost of electric tubewells is Rs. $20-30$ billion annually which can be reduced by $30 \%$ by introducing energy-efficient measures such as use of submersible pumps. The potential savings will be manifold if all the tube-well are considered for energy efficient retrofits and energy auditing. The Agriculture Department Punjab conducted an energy audit of 210 tube-well in Faisalabad region during 2017.

The majority of the tube-well was turbine type and few having submersible pumps. The results showed that energy consumption efficiency of 110 tube-well under study is only $32 \%$, which can be increased to $75 \%$. There is a massive loss of $40 \%$ in energy consumption by electric turbine tube wells. $68 \%$ of the surveyed tube-well have improper size of motor and pump. The main reasons for poor efficiency of pumps identified in this study are improper design of tube well, higher rated power source, aging equipment, improper maintenance and repair, poor transmission efficiency, and inadequate knowledge of operation of tube-well. The design of tube-well can be matched by using energy-efficient components and proper matching of components. The selection of an appropriate pumping system is a big issue as farmers do not have access to engineers or a regulatory body that could guide them and provide services for tube well installation and efficient use of groundwater. The financial implications of rehabilitation of 1500 electrical turbine tube-well were also studied and concluded that investment cost should be recovered in 4 years, depending upon the depth of water table.

\section{Opinion}

According to the author's opinion, following measures should be taken immediately to overcome the energy crises and the sustainability of agriculture growth.
a. Promoting renewable energy technologies
b. Targets for standardization of energy-efficient equipment
c. Conducting an energy audit of industry

d. Arrange the training workshops for creating awareness among the industry and end-users have been fixed under the aforementioned approved project.

e. It is expected that developing countries will reduce their energy wastage.

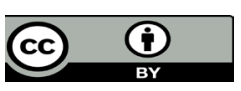

This work is licensed under Creative Commons Attribution 4.0 License

To Submit Your Article Click Here: Submit Article

DOI: 10.32474/CIACR.2019.07.000273

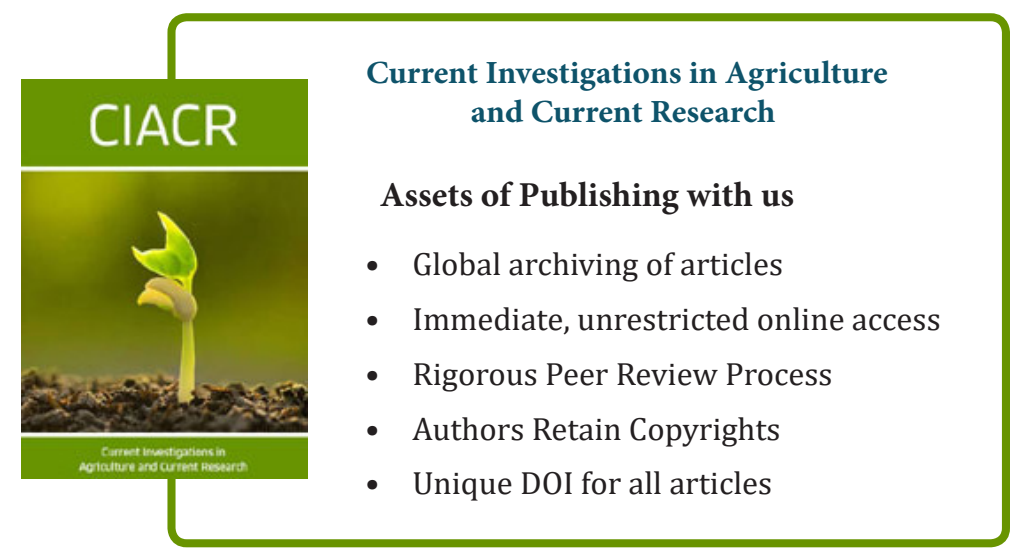

